\title{
Sosyal Medyanın Kamuoyu Oluşturmadaki Rolü ve Muhtemel Riskler \\ ${ }^{1}$ Veysel Eren ${ }^{2}$ Abdullah Aydın \\ ${ }^{1}$ MKÜ İktisadi ve İdari Bilimler Fakültesi, Kamu Yönetimi Bölümü, Hatay \\ ${ }^{2}$ MKÜ İktisadi ve İdari Bilimler Fakültesi, Kamu Yönetimi Bölümü, Hatay
}

\section{"Biz protestoları planlamak için Facebook'u, koordine etmek için Twitter'ı ve dünyaya anlatmak için YouTube'u kullanıyoruz"*}

\begin{abstract}
Özet
Sanayi Toplumundan Bilgi Toplumuna geçişle birlikte, iletişim alanındaki gelişmeler, bilginin üretimi, depolanması, paylaşılması ve eleştirilmesini zamandan ve mekândan bağımsız hale getirmiştir. Sanayi toplumunda bilginin üretilmesi ve paylaşılması hemen hemen her ülkede medya kartellerinin kontrolünde gerçekleşmekteydi. Ancak bilgi toplumuna geçişle birlikte, bilginin üretilmesi ve paylaşılmasıyla ilgili kaynaklar hem çeşitlendi, hem de bilgisayar ve mobil cihaz (akıllı telefon, tablet bilgisayarlar vs...) teknolojisindeki gelişmelere bağlı olarak mekâna bağlılıktan ve periyodik olmaktan kurtuldu. Başka bir ifade ile bilgi belli odakların tekelinden ve iletişim de tek yönlü olmaktan çıktı. Dolayısıyla kitle iletişim araçlarının kullanımının tabana yayılmasıyla (blog, kişisel siteler) bilgi kaynağı çeşitliliği ve bireysel tecrübelerin çok kolay ve hızlı bir şekilde aktarımı sağlanmış oldu. Fakat son dönemde özellikle facebook ve twitter gibi sosyal paylaşım ağlarının ortaya çıkması ve yaygınlaşması, iletişim biçimini, söz konusu klasik anlamından köklü biçimde kopararak, iletișim sürecinin yapısal bir dönüșüme uğraması sonucunu doğurdu. Böylece iletişim tam olarak, interaktif, çok boyutlu ve karşılıklı bir etkileşim sürecine dönüştü. Soysal medya alanındaki bu hızlı ve esaslı gelişme, bireyden başlayarak bir ülkedeki veya toplumdaki her unsuru daha görünür ve kolay ulaşılır hale getirmiş, yani onlara ait sırları (bunlar devlet sırrı olabilir) ve gerekli bilgileri (bunlar firmaların stratejileri olabilir) erişilebilir kılmıştır. Bu durum bir yönüyle şeffaflaşma ve karşılıklı kolay bilgi alışverişi anlamına gelmekte; fakat diğer yönüyle de art niyetli kişilerin elinde bireyler ve toplum için bir tehlikeye dönüşme riski taşımaktadır.

Yapılan bu çalışmada sosyal medya olarak adlandırılan bu yeni iletişim sahasının özelliklerini ortaya koyarak sosyal medyanın klasik medya araçları olarak adlandırılan medya araçlarından farkı üzerinde durulmakta; daha sonra, kamuoyu oluşturmadaki etkileri ele alınmakta ve bu kamuoyu oluşturma veya yönlendirme süreci içerisinde oluşan ve oluşabilecek muhtemel risklere değinilmektedir. Bu bağlamda sosyal medyanın sunduğu imkânların barındırdığı riskler ve güvenlik anlayışına yapmış olduğu olumlu olumsuz katkılar tahlil edilmektedir.
\end{abstract}

Anahtar Kelimeler: Sosyal Medya, Kamuoyu, Güvenlik, Riskler

\section{Role of Social Media Creating Public Opinion and Possible Risks}

\section{Abstract}

With the transition from industrial society to information society, developments in the field of communication, information production, storage, sharing, and criticism has become independent of time and space. In Industrial society, in almost every country information generation and sharing had been controlled by cartels of the media. However, with the transition to an information society, this information generation and sharing of resources, diversified and on the computer and mobile device (smart phone, tablet PC s, etc ...), depending on the developments in space technology and periodically released from commitment. In other words, information is no longer a one-way communication is also certain people and monopoly. Therefore, the use of the mass media in the spread of the base (blog, personal sites ), and the variety of sources of information were transferred to individual experience was very easy and fast way. But recently especially spread of social networks such as Facebook and twitter changed communication format, firmly rooted in the classical meaning of the breaking, resulted in the transformation of a structured communication process. But social networks such as Facebook and twitter especially the recent emergence and spread of networks, communication format, is firmly rooted in the classical meaning of the breaking, resulted in the transformation of a structured communication process. So communication is fully interactive, multi-dimensional and turned into a process of mutual interaction. This rapid and substantial progress in the field of generic media from individuals to each element of a country or society, making it more visible and easily accessible, ie, trade secrets related to them (they can be a state secret), and the necessary information (which may be strategies of firms ) have become accessible. This means that an aspect of the transparency and mutual exchange of information easier, but also other aspects of the hands of ill-intentioned people who are at risk of transformation to a danger to individuals and society.

In this study, the so-called social media site features by introducing new communication tools, social media, traditional media, the emphasis is on the socalled media tools, the difference is then discussed and the effects of the public in forming public opinion in the process of creating or forwarding, and potential risks are discussed. In this context, the full potential of social media has made positive and negative contributions to the understanding of the risks associated with, and security are analyzed.

Key Words: Social Media, Public Opinion, Security Risks

\section{Giriş}

Teknolojik gelişmeler ve bu gelişmelerin sunduğu iletişim olanakları bireylerin çevrelerini algılama ve kritik yapabilme gücünü artırmıştır. Yeni medya olarak isimlendirilen bu iletişim olanakları, bireylerin iletişim için bilgisayar ve benzeri diğer mobil cihazları internet üzerinden etkileşimli bir şekilde kullanmasına kapı aralamıştır. Başka bir ifade ile yeni medya, internetin etkileşimli iletişim gücünü anlatmak için kullanılan soyut bir kavramdır ve bu gücü kullanan araçlar da sosyal medya araçları olarak adlandırılmaktadır. Bireyin çevresinde ortaya çıkan sosyal, kültürel, ekonomik, yönetsel gelişmeler sosyal medya araçları üzerinden hızlıca yayılmakta ve insanların bu içerikleri tartışabilmeleri mümkün olmaktadır. Sosyal medyanın bilgiyi bu şekilde kolay erişilebilir ve paylaşılabilir kılması, bireylere eriştikleri veya kendilerine iletilen bilgilerle ilgili tartışma ortamı 
oluşturabilme ve grup kurma olanağı sunması, diğer bireylerin konuyla ilgili düşüncelerini anlık izleyebilmesine ve bunlara kendilerinin de katılabilmesine imkân sağlaması gibi özellikleri, onun kamuoyu oluşturmadaki ve politik alandaki rolünü tartışmasız biçimde güçlendirmiştir.

Sosyal medyanın etkileşimli iletişim imkânı, bireyi içinde yaşadığı toplum ve devletle ilişkilerinde edilgen (pasif) olmaktan çıkarıp, etken (aktif) bir konuma yükseltmiştir. Bu durum, birey-aile, birey-toplum, birey-devlet ilişkilerinin geleneksel kodlarını bozmuş ve bu ilişkileri birey merkezli olarak yeniden şekillendirmiştir. Sosyal medya, artık insanlar için haberleşme ve iletişim aracı olmanın ötesine geçerek, bir sosyalleşme ve kendini ifade edebilme, içinde yer aldığ 1 her düzeydeki örgütlü yapılara katılma platformlarına dönüşmüştür. Özellikle Facebook ve twitter gibi sosyal ağlar, kullanıcılarına tanışma ve mesajlaşmanın ötesinde, organizasyon kurma, organize olma, bilgi ve fikir paylaşma, inanç ve düşünceler etrafında gruplaşma imkânlarını da vermiştir (Boyd \& Ellison, 2008: 213). Öyle ki, günümüzde sosyal ağlar, rejim değiştirmek, hareket başlatmak üzere kamuoyunu harekete geçiren birer organizasyon araçları haline dönüşmüştür. Bu durum sosyal ağların, demokrasi algısı ve uygulamasını da, temsili demokrasiden katılımcı (doğrudan) demokrasiye doğru dönüştürme gücüne ve imkanına sahip olduğu şeklinde değerlendirilmektedir (Çildan vd., 2012: 2). Başka bir ifade ile sosyal ağlar, yalnızca kamuoyu oluşumuna katkı sağlamakla kalmamakta, ayrıca ve belki de daha önemli bir biçimde sosyal hareketlerin planlandığı, organize edildiği, başlatıldığı ve yönetildiği önemli araçlara dönüşmektedir.

Sosyal medya, bir yandan bireyi hayatın merkezine yerleştirirken, diğer yandan da, giderek güçlenen ve karmaşıklaşan, anlaşılamaz ve baş edilemez bir mekanizmaya dönüşen devlet ve bürokrasiye karşı bireylerin örgütlenmesine ve özgürleşmesine zemin hazırlayan sivil toplumun gelişimini de hızlandırmaktadır. Sivil toplum, kamuoyu oluşumunda en önemli aktörlerden birisidir. Bu nedenle sosyal medyanın sivil toplumun oluşmasına ve güçlenmesine etkisi, kapsamlı biçimde incelenmeyi hak etmektedir. Ancak sosyal medyanın örgütlü birimlerce kötüye kullanılabilme ihtimali de göz ardı edilmemelidir. Görüşlerin, önerilerin, fikirlerin bilginin ve haberin bu kadar hızlı ve özgürce yayılabildiği bir ortam olması, yani özgürlük alanının bu kadar geniş olması birçok bakımdan iyi olduğu gibi birçok bakımdan da sakıncalar içermektedir. Çünkü özellikle hassas konularda insanların manipülasyona açıklıklarının fazla olduğu yani kasıtlı ve yanlış yönlendirilmeye müsait olduğu durumlarda ortaya çıkan bilgi kirliliği, önü alınamayacak durumları doğurur.

$\mathrm{Bu}$ çalışma, bilgi ve iletişim teknolojisindeki gelişmelerle birlikte, bu olanakların, bireylerin kamusal konularla ilgili kanaat, tutum ve tepkilerini nasıl biçimlendirdiğini, dünyadan ve Türkiye'den örnekleriyle ortaya koymayı amaçlamaktadır. Ayrıca bu çalışmada, sosyal medya, sosyal ağlar ve yeni medya olarak isimlendirilen bu unsurların kamuoyu oluşumundaki rolü ve muhtemel riskleri üzerinde durulmakta, bu risklerin azaltılması için yapılması gerekenlere projeksiyon tutmaktadır.

\section{Kamuoyu, Yeni Medya, Sosyal Medya, Sosyal A Kavramları}

Kamuoyu halkın kendisini ilgilendiren bir mesele hakkındaki genel kanaat ve düşünceleri demektir. Bir başka ifadeyle, toplum hayatının çeşitli güçlük ve problemleri karşısında belirli bir zamanda, belirli bir yerde, belirli bir insan grubu arasında yaygın düşünce ve bakış açılarını anlatan bir kavramdir. Daha dar ve sosyolojik anlamda terim, kamuyu ilgilendiren bir konuda halkın kanaatlerinin toplanması ve bunların örnekleme tekniğiyle istatistiklerinin yapılmasına işaret eder.

Yeni medya kavramı küreselleşme ile paralel gelişen birçok yerde vurgu yaptığımız insan, bilgi, belge, fikirlerin mobilitesinin artması ile basılmış yayınlar ve televizyon gibi haber kaynaklarının dışında kalan medya için kullanılan bir tanımlamadır. Aslına bakarsanız yeni medya kavramı bugün internet tabanlı olmayan hiçbir mecra araç ve ortamı kendisine taban almama durumuna gelmiştir. Fakat haber alma özgürlüğünün yetersiz hileli bir özgürlük olması bunun yerine haberleşme (yani karşılıklı haber, bilgi ve fikrin aktarılması) özgürlüğünün sağlanması yalnızca internet tabanlı olmak zorunda değildir. Dolayısıyla Yeni medya kavramını sadece internet tabanına sıkıştırmak gün geçtikçe artan ve değişen teknolojik imkanları yok saymak olur (wikipedia.org, sosyal medya).

Günümüzde giderek gelişen ve yaygınlaşan internet teknolojisi ve sosyal etkileşim, sosyal medya olgusunu oluşturmaktadır. Web 2.0, sosyal ağ ya da sosyal iletişim siteleri olarak da ifade edilen bu alan, yeni kuşak internet uygulamalarını içermektedir. Sosyal medya, kullanıcılara enformasyon, düşünce, ilgi ve bilgi paylaşım imkanı tanıyarak karşılıklı etkileşim yaratan çevrimiçi araçlar ve web siteleri için ortak kullanılan bir terimdir. İnsanların düşünce, görüş ve ilişkilerini internet üzerinden paylaştıkları bir ortam sunmaktadır.

Sosyal medya, adında medya olmasına rağmen geleneksel medyadan farklılık göstermektedir. Özgünlüğünü yaratan en önemli farklılığı, herhangi bir bireyin sosyal medyanın içeriğini yaratabilmesi, yorumda bulunabilmesi ve katkı sağlayabilmesidir. Metin, ses, video, resim paylaşımına olanak sağlamakta, bu özelliği ile de kullanıcılara geniş bir kullanım olanağı sunmaktadır.

Basit bir anlatımla sosyal medya, kullanıcıların internette aradığı, kullandığı ve paylaştığı içeriği gene kendilerinin ürettiği bir platformdur. İnternet kullanımının halkın her kesiminin kullanacağı bir dönüşüme uğraması ve yaygınlaşması ile birlikte ilk dönemdeki tek yönlü paylaşımlar değişime uğramış ve kullanıcılar internet sitelerindeki içeriklere yorum olarak katkıda bulunabilmeye başlamışlardır. Bu süreçte sosyal medya kavramına geçişin ilk adımlarının bloglar ve sözlük siteleri oldukları söylenebilir.

Sosyal Ağ kavramı aslında toplumun bireyleri binlerce yıldır bulunan bir haberleşme, bilgi paylaşımı ve etkileşim sağlayan bir ağ olarak tanımlanabilir. Diğer bir ifade ile kendi içinde ve hatta farklı gruplarla temas içerisinde bulunan bir grubun oluşturduğu bilgi ve fikir birlikteliği anlamına gelir. Sosyal ă̆ kavramı internet dönüşümünün yaşanması ile birlikte yeni bir anlama bürünmüş veya evrilmiştir. Sosyal ağ internet üzerinden birbiri ile bir şekilde irtibatlı bir ağ 
topluluğunu ifade etmektedir. İnsanlar bu sosyal ağlar sayesinde gerçekte tanıdıkları veya tanımadıkları insanlar ile iletişim kurup fikir alışverişinde bulunabilir. Spesifik bir konu hakkında görüş alışverişinde bulunup organize olabilirler.

Genel olarak internet ya da iletişimi kolaylaştırmak için tasarlanmış mobil tabanlı sosyal alanlarda, işbirliği ve ağlar arası ilişkileri anlatan sosyal ağlar her geçen gün üye sayılarını arttırarak daha geniş kitlelerle buluşmaktadır. Bu ağlar arasında en yüksek üye sayılarıyla sırasıyla Facebook, Twitter ve Linkedin göze çarpmaktadır (Tablo 1). Bu ağların varlığı ve üye sayılarının artması, giderek daha fazla bilginin bireyler arasında paylaşılması anlamına gelmektedir. Bu da kamuoyu oluşumu için temel şartlar olan bilgi sahibi olma ve bilgiyi paylaşma (iletişim) imkanlarının artmasına hizmet etmektedir.

Tablo 1: Dünyada Sosyal Ă̆ Sitelerinde Top 10

\begin{tabular}{|l|l|r|}
\hline Sirası & Sosyal Ăg & Üye Sayısı \\
\hline 1 & Facebook & $750,000,000$ \\
\hline 2 & Twitter & $250,000,000$ \\
\hline 3 & Linkedin & $110,000,000$ \\
\hline 4 & Pinterest & $85,500,000$ \\
\hline 5 & MySpace & $70,500,000$ \\
\hline 6 & Google Plus + & $65,000,000$ \\
\hline 7 & DeviantArt & $25,500,000$ \\
\hline 8 & Live Journal & $20,500,000$ \\
\hline 9 & Tagged & $19,500,000$ \\
\hline 10 & Orkut & $17,500,000$ \\
\hline
\end{tabular}

Kaynak: Top 15 most, 2013,

http://www.ebizmba.com/articles/social-networking-websites

Sosyal Medya ülkemizde de yaygın olarak kullanılmakta, ülke gündemine etki eden birçok konu sosyal medya üzerinden gündeme gelmektedir. Halihazırda Facebook, Pinterest, Twitter, Tumblr, Linkedin, MySpace, Youtube Google+ gibi sosyal medya siteleri Türkiye'de en çok tıklanan ve en çok vakit geçirilen internet siteleri olmakla birlikte, ülkemizde 35 Milyon internet kullanıcısın 31 Milyonu Facebook, 6 Milyonu Twitter, 1 Milyonu Google+, 1 Milyonu ise Linkedin üyesidir (Kartal, 2013).

İlkbahar 2012 tarihli "Pew Research Center Global Attitudes Project" verisine göre, Türkiye nüfusunun sadece yüzde 43'ü internet kullanıyor. İnternet penetrasyonu düşük ama internete girenlerin yüzde 81'i sosyal medyayı kullanıyorlar. Aynı verilere göre, Türk kullanıcıların \%69'unu 18-29 yaş grubundaki gençler oluşturmaktadır. Kasım 2012 tarihli comScore Media Metrix verisine göre Türk sosyal medya kullanıcılarının sosyal medyada bir ay içinde geçirdikleri süre 8,6 saat. Bu süre Türkiye'yi dünyada 5. sıraya yerleştiriyor. GlobalWebIndex' in 2012'in dördüncü çeyrek verisine göre ise Türk internet kullanıcılarının bir günde sosyal ă sitelerinde geçirdikleri süre 1,94 saat; mikrobloglarda ise 1,09 saat. Bu iki verinin toplamı 3,03 saat, comScore'un verisinden çok yüksek olsa da GlobalWebIndex'e dahil 31 ülke arasında Türkiye'yi 10 . siraya yerleştiriyor (Öğüt, 2013).

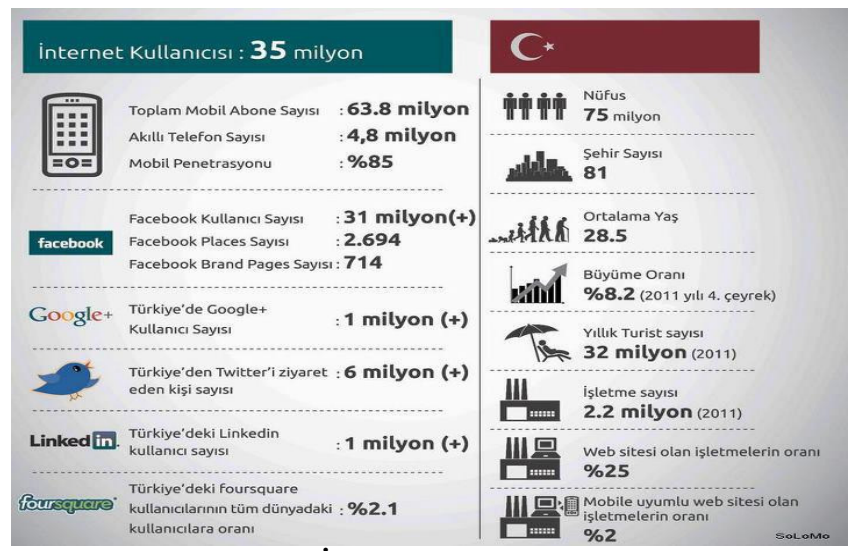

Şekil 1: Türkiye'de İnternet ve Sosyal Medya Kullanımı (www.serhanyildiz.net.tr)

Konumuz açısından sosyal medyanın oluşturduğu en büyük tehdit, yukarıdaki tabloda yer alan çeşitliliğin aksine bu alanda ortaya çıkan tekelleşmedir. Günümüz itibariyle milyonlarca sitenin yer aldığı Sosyal Medyada, Google, Facebook, Twitter, Microsoft gibi şirketler giderek tekelleşmektedir. Özellikle ABD İstihbarat kurumlarıyla anılagelen Facebook, Twitter gibi Sosyal Medya kuruluşları akıllı telefon teknolojisiyle daha geniş kitlelere ulaşma imkanı ve kullanım alanı bulmuştur.

Dünyadaki kapitalist sistemin iki temel özelliğinden birisi bu sistemin gelişmiş ülkeler lehine çalışması, diğeri de sürekli krizlerle karşı karşıya kalmasıdır (Amin, 2011). Sistemin sürdürülebilmesi ve krizlerin atlatılabilmesi için her dönemde farklı araçlar ve yöntemler geliştirilmiş ve kullanılmıştır. Günümüz bilgi toplumunda da bu amaca hizmet edecek en önemli enstrüman sosyal medyadır. Gelişmiş ülkelerin ellerindeki teknolojik imkanlar ve istihbarat gücüyle sosyal medyayı kullanarak, diledikleri ülkelerde operasyon başlatmaları ve istedikleri yönde politika ve iktidar değişikliklerini gerçekleştirmelerinin önünde hiçbir engel bulunmamaktadır.

\section{Sosyal Medyanın Kitleler Üzerindeki Etkisi: Wall Street ve Diğerleri}

Sosyal medyanın gücünü anlamak için, dünyanın süper gücü olarak bilinen ABD'de, bu gücün simgesi haline gelen Wall Street'te yaşanan olayları incelemek yerinde olacaktır. ortaya koyacağımız diğer bir örnek de, dünyada son dönemde hızla yayılan halk ayaklanmalarının simgesi haline gelen, Wall Street'i İşgal Et hareketidir. Başlangıçta basit bir protesto gibi görünse de ilerleyen zamanlarda farklı olaylarda da "occupy" sözcüğüyle sloganlaşması ve belli sembollerle ifade edilmesi, artık bir hareket haline geldiğinin açık göstergesidir. Bu hareket, ABD'de 1968 hareketlerinden bu yana gerçekleşmiş en önemli politik olay olarak karşımıza çıkmaktadır.

Wall Street olayları, Bush döneminden beri devam eden ekonomik daralmanın sadece fakir Amerikalıları değil giderek genişleyerek orta sınıfı da vurmaya başladığını göstermiştir. 2011 yılında halkın suçlu arama refleksinin sonucu olarak gerçekten abartılı bir zenginlik ve üst düzey sömürü kanallarına sahip Amerikan nüfusunun en zengin yüzde 1'inin bulunduğu sınıfa karışı eylemler meydana gelmişti. Eylemlerin başladığı ilk birkaç günü içine alan ilk evrede, hareket gösteri yapmaya çalışan bir avuç cesur, 
çoğunlukla genç insandan meydana gelen bir eylemci profiline sahipti ve bu evrede basin onları tamamen görmezden gelmiş. Hatta görünmeyeceğini düşünerek polis aşırı güç kullanma yoluna gitmişti. Tabi bunu yaparken olacakların bu noktaya gideceği tahmin edilmemişti. Çünkü polislerin yaptıkları yanlış uygulamalar ve orantısız güçle ilgili sahneler kameraya alınmış ve videolar değişik ellerden Youtube ve benzeri video paylaşım siteleri aracılı̆̆ çapına yayılmıştı. Eylemcilerin sosyal medya olanaklarını kullanması onları görünür hale getirmiş, bu noktada bu eylemler kamusal bir mesele ve sorun haline bürünmüştü. Moda tabirle ana akım medya artık göstericileri tamamen görmezden gelemiyordu. Bunun yerine onların marjinal olduklarına toplumdan kopuk bir diğer tabirle birkaç serseri olduğuna vurgu yapılıyordu. Ama diğer yandan ise eylemlere katılım artıyor, toplumun değişik kesimlerden destekler geliyor ve Ana akım medyanın söyledikleri dışında bir kamuoyu oluşuyordu. Nihayet olaylar, birçok ünlü kişinin de desteğini alan bir yapıya bürünmüş ve eylem artık bir sonraki aşamaya terfi etmiştir. Bu aşamada artık eylemler meşruiyet kazanmıştı. Yani yapılan eylemlerin haklı dayanakları olduğu birçok kesim tarafından kabul görmeye başlamıştı. Hatta merkez medyanın ABD için amiral gemisi olan New York Times'ta, Başyazısında protestocuların aslında "açık bir mesajları ve spesifik politika önerileri" olduğu ve hareketin "bir gençlik başkaldırısının" ötesinde bir nitelik gösterdiği yazıyordu. New York Times şöyle devam ediyordu: "Aşırı ölçülere varan eşitsizlik, üretken yatırımların olduğu kadar spekülasyonun, para sızdırmanın ve hükümet desteğinin yönlendirdiği bir finans sektörünün hâkimiyetindeki bozuk bir ekonominin alamet-i farikasıdır. Bu ifadeler New York Times gibi bir gazete için inanılmaz derecede cesur bir dildir (Wallerstein, 2011).

ABD toplumunun her kesimine bir şekilde görüşlerini ya da önerilerini ulaştıran bu eylem, yukarıda ifade edilen aşamalardan geçerek bu güne gelmiştir. Dünyanın birçok yerinde gerçekleşen farklı olaylarda da buna benzer seyir izleyen sosyal medya kaynaklı eylemler gücü elinde bulunduranların bir şekilde engel olamadıkları bir hale bürünmüştür. Burada ifade ettiğimiz Wall Street'i İşgal Et (Occupy) hareketi ise daha sonraki dönemde iç tükenme veya baskı yoluyla zayıflamaya başlasa bile, daha şimdiden başarılı olmuştur. Çünkü birkaç kişi tarafından başlatılan bu tarz bir eylem artık sosyal bir olguya dönüşmüş toplumun her kesimini etkileyen-ilgilendiren bir hal almıştır. Sosyal Medyanın gücü ve doğurduğu durum ABD için bile yeni karşılaştığı ve tecrübe ettiği bir durum olmuş ve kendi adına birçok ders çıkartmıştır.

Sosyal medyanın kitleler üzerindeki etkisi ve harekete geçirici gücü, birçok Avrupa ülkesinde de tecrübe edilmiştir. Nitekim Paris banliyösü Clichy-sous-Bois'da polisten kaçan iki Kuzey Afrikalı göçmen gencin elektrik akımına kapılarak ölmelerinden sonra başlayan ve hızla yayılan şehir isyanları da sosyal medya aracılığıyla örgütlenip yönetilmiştir. Diğer taraftan 15 Mayıs 2011'de İspanya'nın 50 farklı şehrinde es zamanlı olarak başlatılan ve "öfkeliler" olarak anılan grupların eylemleri de sosyal medya üzerinden örgütlenip yönetilmiştir. Avrupa'nın çeşitli ülkelerinden benzer biçimde sosyal medya üzerinden başlatılan ve yönetilen eylem örneklerini artırmak mümkün olmakla birlikte, Sosyal Medyanın kitleler üzerindeki gücü, Orta Doğuda yer alan diktatörlere karşı başlatılan halk hareketlerinde (Arap Baharı) daha iyi anlaşılmış oldu denilebilir.

Arap Bahar ${ }^{1}$, Tunus, Misır, Libya, Suriye, Bahreyn, Cezayir, Ürdün ve Yemen'de büyük çapta; Moritanya, Suudi Arabistan, Umman, Irak, Lübnan ve Fas'ta küçük çapta olmak üzere tüm Arap Dünyasında baş gösteren mitingler, protestolar, halk ayaklanmaları ve silahlı çatışmaların genel adıdır. Birçok uzman tarafından 21. Yüzyılın en büyük olayı ve Arap dünyasında yaşanan en büyük değişim olarak nitelendirilmektedir. Aşağıda Arap dünyasında yaşanan bu olaylar Tablo 2'de özet olarak sunulmuştur. Her ülkede sosyal hareketlerin nedenleri belli ölçüde farklılıklar gösterse de, bu nedenlerin kesiştiği kısımlarda iktidar etme tarzı, işsizlik, yolsuzluk, adaletsiz uygulamalar ve genel olarak devlet yönetiminden memnuniyetsizlik olduğu söylenebilir. Nitekim Arap ülkelerinde ortaya çıkan sosyal hareketler, büyük çaplı protesto gösterilerine dönüşmüş, bazı ülkelerde hükümetin yenilenmesine veya politikalarını gözden geçirmesine neden olurken, bazı ülkelerde ise hükümetin yıkılmasına hatta iç savaşlara neden olmuştur.

Arap ülkelerinde yaşanan devrimlerle ilgili yapılan bilimsel bir araştırmada 3 milyondan fazla tweet, binlerce blog gönderisi ve yüzlerce gigabytelık YouTube videosu incelenmiştir. Sonuçta, sosyal medyanın Arap Baharı'ndaki siyasi tartışmaların şekillenmesinde oldukça merkezi bir rol oynadığı ve büyük olaylar öncesinde sık sık devrim hakkında online konuşmalar yapıldığı ispatlanmıştır. Tunus ve Misır özeline odaklanan bu araştırmada, facebook, twitter ve youTube'ndan toplanan verilerle, Misır'daki siyasi web siteleri, Tunus'un tüm blog küresinde gerçekleşen politik diyaloglar ve devrim esnasında gerçekleşen ve filtrelenen 3 milyon tweet değerlendirmeye alınmıştır. Ortaya çıkan sonuçta, Arap Baharı'nda sosyal medyanın kritik rolü kanıtlanmıştır. Sosyal medya özgürlükler yolunda çok kritik bir araç haline gelmiştir (http:e-siber.com).

\section{Gezi Parkı Protestoları ve Sosyal Medya}

Dünya'da ilk örnekleri ABD ve Avrupa ülkelerinde görülen, fakat daha sonra başta Ortadoğu olmak üzere, gelişmekte olan ülkelerin hemen hepsine sıçrayan, sosyal medya aracılığıyla örgütlenerek hükümetlere, uygulanan politikalara ve kapitalist sistemin çeşitli aktörlerine karş1 gerçekleştirilen protesto gösterilerinin bir halkası da Gezi Parkı Protestoları ile Türkiye' de gerçekleşmiştir. Protestolar, İstanbul Büyükşehir Belediyesi'nin Taksim Gezi Parkı'nı Yayalaştırma Projesini uygulamaya başlaması ve haberin sosyal medya aracılığıyla kısa sürede yayılması sonucu bazı eylemcilerin parka giderek çalışmaları durdurmasıyla 28 Mayıs 2013 tarihinde başlamıştır.

Polisin müdahaleleri ve Başbakan Erdoğan'nın inşaatın yapımında ısrarcı açıklamaları ile protestolar hükümet karşıtı gösterilere dönüşmüş ve başta Ankara, İzmir gibi büyükşehirler olmak üzere Türkiye'nin diğer illerine de yayılmıştır. İçişleri Bakanlığı'nın 23 Haziran'da yaptığı açıklamaya göre Bayburt ve Bingöl hariç 79 ilde düzenlenen eylemlere toplam 2.5 milyon kişi katılmış, bundan daha fazla

1 Birçok ülke, kuruluş ve alanda uzman kimseler, hareketlerin farklılığı ve sürekli sancılı, çalkantılı değişken olması gibi özellikleriyle baharı andırması nedeniyle bu halk hareketine Arap Baharı demişlerdir (tr.wikipedia.org) 
kişi de sosyal ağlar üstünden destek vermiştir (Milliyet, 23.06.2013).

Olaylar sonucunda 6 sivil ve 1 komiser hayatını kaybetmiş, 8163 kişi ise yaralanmıştır. Yine İçişleri Bakanı Muammer Güler'in açıkladığı resmi rakamlara göre, 4 Haziran itibariyle 77 ilde 603'e yakın eylem gerçekleşmiştir. Bu eylemler sırasında 280 işyeri, 1 özel konut, 6 kamu binası, 18 belediye otobüsü, 207 özel araç, 103 polis arac1, bir polis merkezi ve 11 AK Parti hizmet binasının yanı sıra başta Ankara ve İstanbul'da olmak üzere çok sayıda otobüs durağı, trafik ışık ve levhaları, MOBESE kameraları, bankamatikler ve kaldırımlarda çeşitli zararlar meydana gelmiştir. İlk tespitlere göre, bu zararların 70 milyon liranın üzerinde olduğu ifade edilmiştir (tr.wikipedia.org).

Tablo 2: Arap Baharının Yaşandığı Bazı Ülkeler Ve Sonuçları(tr.wikipedia.org)

\begin{tabular}{|c|c|c|c|c|c|}
\hline Ülke & $\begin{array}{l}\text { Başlangıç } \\
\text { tarihi }\end{array}$ & Olay şekli & Değişimler & Ölü sayısı & Sonuç \\
\hline Tunus & $\begin{array}{l}18 \text { Aralık } \\
2010\end{array}$ & $\begin{array}{l}\text { Muhammed Buazizi'nin kendini } \\
\text { yakması, } \\
\text { Ülke çapında protesto, kamu } \\
\text { alanlarının işgali }\end{array}$ & $\begin{array}{l}\text {-Zeynel Abidin Bin Ali ve Muhammed } \\
\text { Gannuşi ülkeyi terk etti } \\
\text { •Politik polis dağıtıldı } \\
\text {-İktidar partisi dağıtıldı } \\
\text {-Siyasi suçlular serbest bırakıldı }\end{array}$ & $223+$ & Devrilen hükümet \\
\hline Yemen & 18 Ocak 2011 & $\begin{array}{l}\text { Ülke çapında protesto ve } \\
\text { gösteriler }\end{array}$ & $\begin{array}{l}\text { - İktidar partisinden bazı milletvekilleri } \\
\text { istifa etti; } \\
\text { - Devlet başkanı Salih } 23 \text { Mayıs'ta } \\
\text { dokunulmazlık verilmesi şartı ile istifa } \\
\text { etmeyi kabul etti. }\end{array}$ & 2,000 & $\begin{array}{l}\text { Yenilenen } \\
\text { hükümet }\end{array}$ \\
\hline Misır & 25 Ocak 2011 & $\begin{array}{l}\text { Ülke çapında protestolar, kamu } \\
\text { alanlarının işgali, devlet ve polis } \\
\text { binalarının yakılması, hapishane } \\
\text { baskınları gerçekleşti. En son } \\
\text { Mısır ordusu, hükümeti devirerek } \\
\text { halka iki kez silahlı saldırı } \\
\text { düzenledi. }\end{array}$ & $\begin{array}{l}\text { •Hüsnü Mübarek ve Ahmet Şefik'in istifası; } \\
\text { •Silahlı kuvvetler gücü ele aldı; } \\
\text { •Parlamento dağıtıldı ve konsey askıya } \\
\text { alındı; } \\
\text { •Devlet Güvenlik Soruşturma Servisi } \\
\text { kapatıldı; } \\
\text { •İktidar partisi dağıtıldı }\end{array}$ & 875 & $\begin{array}{l}\text { Devrilen } \\
\text { hükümetler }\end{array}$ \\
\hline Suriye & 26 Ocak 2011 & $\begin{array}{l}\text { Ülke çapında protestolar, devlet } \\
\text { binalarına saldırı }\end{array}$ & $\begin{array}{l}\text { •Siyasi suçlular serbest bırakıldı; •Bölgesel } \\
\text { valiler kovuldu; } \\
\text { •İsyan bölgelerine askeri müdahale yapıldı; } \\
\text { •Parlamentodan bazı vekiller istifa etti; } \\
\text { •Hükümetten istifalar }\end{array}$ & $100,000+$ & İç Savaş \\
\hline Fas & 30 Ocak 2011 & Protestolar, mülkiyete zararlar & $\begin{array}{l}\text { •Kral Muhammet VI tarafından ekonomik } \\
\text { imtiyazlar verildi; } \\
\text { •Referandum kararlaştırıldı; } \\
\text { •Yolsuzluğu önlemek için adımlar atıldı }\end{array}$ & $\begin{array}{l}7 \text { (2 kişi } \\
\text { ölümüne } \\
\text { dövüldü) }\end{array}$ & $\begin{array}{l}\text { Büyük çapta } \\
\text { protestolar }\end{array}$ \\
\hline Irak & $\begin{array}{l}10 \text { Şubat } \\
2011\end{array}$ & $\begin{array}{l}\text { Büyük protestolar; isyanlar; } \\
\text { devlet binalarına saldırı }\end{array}$ & $\begin{array}{l}\text {-Başbakan Maliki seçimlere aday } \\
\text { olmayacağını açıkladı; } \\
\text { •Valiler ve yerel yöneticiler istifa etti }\end{array}$ & 35 & $\begin{array}{l}\text { Büyük çapta } \\
\text { protestolar }\end{array}$ \\
\hline Bahreyn & $\begin{array}{l}14 \text { Şubat } \\
2011\end{array}$ & $\begin{array}{l}\text { Büyük protestolar, kamu } \\
\text { alanlarının işgali }\end{array}$ & $\begin{array}{l}\text {-Kral Hamad ibn Isa Al Khalifa tarafından } \\
\text { ekonomik imtiyazlar verildi; } \\
\text { •Politik suçlular serbest bırakıldı; }\end{array}$ & 51 & $\begin{array}{l}\text { Büyük çapta } \\
\text { protestolar }\end{array}$ \\
\hline Libya & $\begin{array}{l}17 \text { Şubat } \\
2011\end{array}$ & $\begin{array}{l}\text { Ülke çapında protestolar, silahlı } \\
\text { çatışmalar, şehirlerin işgali }\end{array}$ & $\begin{array}{l}\text { - Muhalifler ülkenin yönetimini ele geçirdi } \\
\text { - Geçici Ulusal Konsey kuruldu } \\
\text { - NATO askerleri Libya üzerinde } \\
\text { operasyonlar düzenledi } \\
\text { - Libya'nın devrik lideri Muammer Kaddafi, } \\
\text { memleketi Sirte'de yakalanarak öldürüldü. }\end{array}$ & $\begin{array}{l}25,000- \\
30,000\end{array}$ & Devrilen hükümet \\
\hline
\end{tabular}

Protestocuların eylemleri organize etme, duyurma, yönlendirme ve canlı tutmasında başta Facebook ve Twitter olmak üzere "sosyal medya"nın oldukça önemli bir rolü olmuştur. \#OccupyGezi ve \#DirenGeziParki adlı hashtag formatları oluşturulmuştur (Turkish Weekly, 01.06.2013). Sosyal medyanın olayların yayılmasındaki rolünü gösteren bir başka önemli ip ucu da, 31 Mayıs günü akşam 16:00'dan itibaren 12 saat içinde konu ile ilgili 3 ana hashtag grubu için 2 milyon tweetin atılmasidır. Bunların 950 000'i \#direngezipark1, 170 000'i \#occupygezi ve 50000'i \#geziparki'dir. Ayrıca gezi parkında bekleyenlerin kalabalıklaşmasında ve benzer protestoların çeşitli şehirlere yayılmasında sosyal medyanın etkisi görülmüştür (Barbera \& Metzger, 2003).
$\mathrm{Bu}$ denli etkili olan sosyal medyada dolaşan haberlerin doğru olup olmadığını anlık olarak tespit edebilme ve haberin ulaştığı kitlelere doğru bilgiyi gösterebilme olanağı bulunmamaktadır. Söz konusu haberlerin birçoğunun kanıtlanabilirliğinin güç olması bir yana, kitleleri, harekete geçtikten sonra, durdurmak ya da onlarla sağlıklı iletişim geliştirmek de oldukça zor olmaktadır. Henüz olayların ilk haftasında 5 milyon civarında yanlış bilgi içeren "tweet atıldığı" iddia edilmiştir (worldbulletin.net). Gezi Parkı protestoları sosyal medya aracılığıyla geniş kitlelere ulaşan doğruluğu şüpheli ve tamamen yanlış birçok haberle kamuoyunda büyük bir bilgi kirliliği ve dezenformasyon oluşturmuştur.

Gezi Parkı eylemleri sırasında da birçok yanlış bilgi, resim ve video kullanılmıștır. Yabancı bir ülkede bot 
motorundan yaralanan bir gencin Türkiye'deki gösteriler sırasında panzerle ezildiği, sosyal medyaya erişimin engellendiği, binlerce polisin istifa ettiği, İstanbul Emniyet Müdürünün görevden alındığı, polisin gerçek mermi

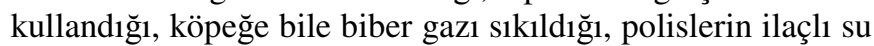
kullandığı, eylemlerin 48 saat daha devam etmesi durumunda Anayasa Mahkemesinin hükümeti düşürebileceği, eylemcilere karşı portakal gazı kullanıldı̆̆ı gibi daha birçok yalan haber kullanılmıştır.

\section{Sosyal Medya'nın Topluma Etkileri ve Kamuoyu Oluşumundaki Rolü}

Sosyal medyanın topluma etkileri ve kamuoyu oluşumundaki rolünden bahsetmeden önce dikkat çekilmesi gereken çok önemli bir husus vardır. İnternet ve sosyal medya, yetişkinlerden çok gençler tarafından kullanılmaktadır. Yetişkinlerin önemli bir kısmı ya maddi imkanı olduğu halde (bilgi eksikliği nedeniyle) bu araçları kullanamamakta veya ekonomik imkansızlıklar nedeniyle bu dünyadan uzaklarda yaşamlarını sürdürmektedir.

Yönetim paradigmasında yönetimden yönetişime geçişi besleyen en önemli unsur sosyal medyadır. Sosyal medya tüm dünyada yurttaşlar arasındaki demokrasi ve özgürlük talebinin yayılmasında ve artmasında güçlü bir iletişim aracı işlevini yerine getirmektedir. Az gelişmiş veya gelişmemiş ülkelerde yaşayan yurttaşlar sosyal medya sayesinde gelişmiş ülkelerdeki refah ve demokrasi seviyesini öğrenme, dünyayla bütünleşme imkânı bulabilmekte ve kendi taleplerini yönetimlerine karşı dile getirme olanağı bulmaktadır. Bu yeni yapıda, kamu politikalarının oluşturulma ve uygulanma süreci, merkeziyetçi ve tek yönlü yönetim anlayışının yerine, yurttaşlarla yönetimin interaktif biçimde işbirliğini zorlayan yeni bir yaklaşımı gerektirmektedir. Ayrıca yönetsel süreçler, yönetişimin diğer öğeleri olan şeffaflık, özgürlük ve demokrasi ilkelerinin göz önünde bulundurulmasını zorunlu kılmıştır. Tam da bu noktada sosyal ağlar temsili demokrasiden, katılımcı demokrasiye geçişte büyük bir role sahip olmaktadir.

Sosyal medyada var olan bir içerik kullanıcı tarafından oluşturulduğundan yaratıcılık, aykırılık ve farklılık önem kazanmaya başladı ve katılım çağı doğdu. Diğer bir anlatımla bir büyük sanayi kuruluşu gibi üretim tesisi olan büyük medya kuruluşlarının hegomanyası kırıldı ve artık medya'nın içeriğini üreten ve medyayı izleyen arasındaki katı ayrım ortadan kalktı. Bununla beraber değişim hızı da arttı. İnsanlar için innovatif olmak ve yeniliklerde başı çekmek önem kazandı. Derinlemesine baktığımızda ise gerçekler değil fikirler önem kazand,, objektif olmak değil içten olmak önemli hale geldi. Yani asıl olan ilgi çekmek ve karşı taraftakini direkt olarak etkilemek oldu. Bu da insanın fikrini ya da kendisini bir ticari mal gibi reklama muhtaç bir kisveye büründürmüştür. Çünkü reklam yapmanın temelinde yatan ne olursa olsun ne şekilde olursa olsun ilgi çekmek ve tercih edilmeyi sağlamaktır. Bu noktada ifade edilmesi gereken en önemli husus sanal ortamın getirdiği realiteden uzaklığın aslında insanların birebir ya da maddi olarak karşı karşıya gelememesinden kaynaklanmaktadır, yani yüz yüze görüşmeyen birbirlerinin gözleri içerisine bakmadan anlatımda bulunan insanlar birbirlerine her konuda daha acımasız ve pervasız oluyorlar. Bunun bir göstergesi de sosyal medyanın yeni bir ilişkiler ağı ve iletişim jargonu ortaya çıkarmasıdır. Bir müstear (ya da diğer bir ifade ile nickname) ismin arkasına saklanmış olmanın verdiği özgüven bireylere muazzam bir ifade özgürlüğü bahşetmiştir. Dolayısıyla artık insanlar bilinçaltının derinliklerinde mahsur kalmış duygu ve düşünceleri rahatlıkla toplumun veya karşıdakinin değer yargılarını göz ardı ederek ifade edebilir hale getirmiştir.

Aslında Sosyal medya kullanımında içerik olarak nitelendirilen bilgi, fikir ve haber gibi şeyleri ekleyen her birey bunu yapmakta özgür olduğundan bunu yapmakla diğer insanlarla eşit olduğunu hissetmektedir (en azından her içerik paylaşan insanla). Bu his insanların kafasında demokrasi fikrinin yerleşebilmesi için uygun ortam sağlamaktadır. Bu durum, kişilerin internette öne sürdükleri düşüncelere, paylaşımlara, tanıdıkları olsun olmasın, diğer paylaşımcıların yaptıkları yorumlar ve geribildirimlerle bir sosyal etkileşim alanı ve giderek sanal cemiyetler oluşturmaktadır. Batı dünyasının sürekli olarak teknolojik gelişmeleri demokrasiyi yaygınlaştırıcı araçlar olarak pazarlaması, baskıcı rejimlerin internet üzerindeki faaliyetlerini sadece internet sitelerini kapatmak veya internet sitelerine erişimi yasaklamaktan çıkarıp, sosyal paylaşım sitelerini protestocuları takip etmekten tutun, kendi propaganda sitelerini kurmaya kadar genişleyen bir yelpazede pozisyon almaya yöneltebilmektedir (tr.wikipedia.org, sosyal medya).

\section{Sosyal Medyanın Kamuoyu Oluşumundaki Rolü Bağlamında Muhtemel Riskler}

Sosyal medya ile gelen tehditlerin bir kısmı özel yaşam ve aile kurumuna yönelik iken, bir bölümü kişisel, bir bölümü de toplumsal boyutta söz konusudur.

1) Sosyal Mühendislik Saldırıları: Sosyal medyanın toplumsal olayların hızlı ve kolay organize edilmesine olanak sağlaması, ülke içinden ve dışından veya ikisinin işbirliğine dayalı sosyal mühendislik saldırıları düzenlenmesini kolaylaştırmaktadır. Gerçekten sosyal medya, bireyleri, grupları ya da kamuoyunu belli bir tutum ve davranış konusunda ikna edebilmek için inanılmaz fırsatlar sunmaktadır. Toplumu dizayn etmek için internet bağlantılı bir bilgisayar veya cep telefonu yeterli olmakta, bu yolla geniş kitleler yönlendirilebilmektedir.

2) Provokasyon, dezenformasyon ve tahrik: Sosyal mühendislik saldırılarında da bu yollara başvurulsa da, bu imkanlar, daha geniş bir kullanım alanı bulmaktadır. Sosyal medyanın, provokasyon, dezenformasyon ve tahrik imkanından, özel yaşamdan ticarete, kişisel amaçlardan grup veya farklı ülkelerin istihbarat amaçlarına kadar hemen her alanda karşı tarafa belli bir düşünce, tutum veya davranışı benimsetmek için yararlanılabilmektedir.

3) Bağımlılık: Ülkelerin geleceği genç nesillerdir. Bu nesillerin, oyunlar, filmler veya sosyal medya araçlarına bağımlı hale getirilmesi başlı başına büyük bir tehdittir. Buna bir de gençlerin provokasyona açık olmalarını eklediğimizde, kötü niyetli sistematik uygulamaların nasıl bir tehlike olduğu daha iyi anlaşılacaktır.

4) Akıllı telefon uygulamalarıyla zamandan ve mekândan bağımsız biçimde kullanılabilmesi: Sosyal medyanın yaygınlaşmasının yanında özellikle bir masaüstü bilgisayara benzer özellik gösteren akıllı telefonların halk tarafında 
kullanılabilir olması ile bilgiyi mobil şebekelerden kablosuz bir şekilde almak, kullanmak ve yaymak mümkün olmuştur. $\mathrm{Bu}$ durum, bireylerin dünyanın her yerinden anında bilgi edinmesine ve bu bilgiyi paylaşmasına, sosyal organizasyonlar kurmasına ve bunları yönetmesine olanak sağlamaktadır. Ancak bu sürecin denetim ve kontrolü zor olduğundan, bireylerin tekel yapılar, organize örgütler ve istihbarat birimlerince yönlendirilmesi daha kolay hale getirmektedir.

5) Özel Yaşama ve Aileye Yönelik Tehditler: Yukarıda ifade ettiğimiz bir müstear ismin arkasına sığınarak özgürce hakaret ve en aykırı fikirleri ortaya koyma durumu yine devam etmekle birlikte insanlar gerçek isimlerini ve bilgilerini paylaştıkları ortamlarda da kendilerini göstermeye başlamışlardır. Mesela Facebook gibi sosyal ağlar kullanıcılarını gerçek isim bilgi kullanması konusunda teşvik etmiş hatta kullanmayanların profillerini iptal etme tehdidinde bulunmuşlardır. Bu profillerin oluşması ile kişiler, kullanıcı olarak yarattığı sosyal medyada yayınlanan her içeriğin eninde sonunda halka mal olması ve art niyetli insanlar veya çıkar grupları tarafından kullanılabilir hale gelinebildiği görünmüştür. Bu hale gelmesi sosyal medyanın en çok tartışılan konularından birine dönüşmüştür. Bunun farkında olmadan insanlar özel hayatlarını sosyal medyada yayınlamaya devam ettikçe özel hayatın gözler önünde olması başkaları tarafından ulaşılması sıradan ve kabul edilebilir bir hale dönüşmüştür. Tabi bu olurken insanların bir zaafına değinmeden geçmemek lazım özellikle popüler kültürün ortaya çıkıp gelişmesi ve hatta topluma yerleşmesi ile insanların rol model algısı değişmiş ve Televizyonda gördüğü insanların hayatlarına özenmeye başlamışlardır. Sonrasında bu popüler kişilerin hayatlarını yaşayamasalar da en azından onlar gibi göz önünde olma ya da özel hayatlarını afişe etme kaygısı veya zaafı taşımaya başlamışlardır. Bunun en önemli nedeni sosyalleşmenin insani olanının ancak yüz yüze olanla olabileceği anlayışının zayıflamasıdır.

Diğer yandan sosyal medyanın toplumun her kesimine etkisi olduğu gibi toplumun temel yapı taşı olan aile içerisinde de birçok etkileşime neden olduğu gözükmektedir. Toplumsal değişimlerin kuşaklar arasındaki uçurumu arttırması ve kuşak çatışmasının doğması sanayi ve teknoloji çağının diğer bir ifade ile Tüketim çağının bir ürünü olarak ortaya çıkmıştı. Farklı alışkanlıklar ve deneyimler yaşayan iki nesil arasında oluşan bu farklılıklar birbirlerine yabancılaşmayı, birbirlerine olan toleransın azalması, karşılıklı anlayışı olumsuz etkilemekteydi. Fakat son dönemde Ebeveynlerle çocukları arasındaki iletişim yönü daha farklı bir boyut kazanmış. Ebeveynler şimdiki teknolojik şartlara ayak uydurmada ciddi problemlerle karşılaşmakta ve bunu bir tehlike olarak görmektedirler. Ama bu kaçınılmaz değişimin bir şekilde (çocuklarının olduğu ortama hâkim olma gayreti bu şekillerden biridir) bir yerinde bulunmak isteyen bir üst kuşak temsilcisi ebeveynler bu yeni teknolojik ortama yatkın şartlarda doğan çocuklarının öğrenme hızlarına yetişememişler ve bu yüzden bazı şeyleri çocuklarından öğrenmeye istekli hale gelmişlerdir. Bu öğrenme sonucunda sosyal medyaya daha yatkın hale gelen ebeveynler, çocuklarıyla sanal ortamı paylaşmaya başladılar ve çocuklarının arkadaş çevrelerini de bu yolla daha yakından tanıma olanağına kavuşmuşlarıdır.
6) Tehlikeli Bilgi Paylaşımı ve Manipülasyon: Sosyal medyanın en büyük risklerinden biri, tehlikeli bilgi paylaşımı ve manipülasyondur. Her ne kadar bireylere bilgi ve iletişim alanında geniş özgürlükler sunsa da, sosyal medya, tehlikeli bilgilerin belli bir denetim süzgecinden geçirilmeksizin paylaşılmasına aracılık etmesi nedeniyle, toplumsal düzen, istikrar ve güvenlik açılarından büyük riskler de taşımaktadır. Özellikle çocuklar ve yeterli tecrübeye sahip olmayan gençler söz konusu olduğunda bu risklerin daha fazla ön plana çıktığı görülmektedir.

7) Ekonomik riskler: Sosyal medya, iş dünyasında özellikle çalışanların zamanlarını, enerjilerini ve dikkatlerini çaldığı için ekonomik zararlara da yol açmaktadır. Ayrıca devletlerin ve şirketlerin mahrem bilgilerinin üçüncü kişilerin eline geçmesine olanak sağladığı için de sosyal medya bir risk faktörü olarak değerlendirilebilir. Dünya çapında 1000 'den fazla çalışana sahip 1225 firmanın yetkilileri ile görüşülerek hazırlanan bir rapora göre sosyal medya bir yıl içerisinde firmalarda ortalama $\mathbf{4 , 3}$ milyon dolarlık zarara neden olabiliyor. Araştırmalarda firmaların sosyal medya kullanımının taşıdığı en büyük riskleri şu şekilde ifade ettikleri görülmüştür: Çalışanların çok fazla bilgi paylaşıyor olması (\%46), şirket içi gizli bilgilerin kaybedilmesi/açığa çıkarılması (\%41), marka imajının zedelenmesi (\%40), artan davalara maruz kalma (\%37), kötü amaçlı yazılım (\%37) ve düzenleyici kuralların ihlal edilmesi (\%36) (slideshare.net). Görüldüğü üzere sosyal medya, şirketlerin BT kullanımı bakımından büyük bir risk faktörü haline gelmekte ve bir araştırma soncuna göre de sosyal ağlara erişim \%78 düzeyinde yasaklanmakta ve çalışanların en tehlikeli faaliyeti olarak \%35 ile sosyal ağlara erişim gösterilmektedir (BThaber.com).

Bilgi teknolojisinin sunduğu olanaklar, birey-devlet ilişkilerini yeni bir bağlama taşımış ve bireyin konumunu ve rolünü esaslı biçimde değiştirmiştir. Günümüzde vatandaş olsun veya olmasın her insan birbiriyle sınır tanımaksızın, özgürce ve eşzamanlı olarak iletişim kurabilmektedir. Bu da, devletlerin en azından bilgi ve iletişim üzerindeki kontrolü yitirmelerine neden olmaktadir.

Ayrıca sosyal medya, dezenformasyon yoluyla kitlelerin harekete geçirilmesi ve illegal örgütlerin kontrolüne geçmesine yol açabilir. Böylece kitlelerin yanıltılması, yanlış yönlendirilmesiyle kamu düzeninin bozulması gibi olumsuz sonuçlar doğabilir. Bu tür riskler, iletişim ve bilgi teknolojisi, sosyal medya ve ağlar konusunda yeterli teknik, yasal ve idari altyapının bulunmadığı ülkeler için daha büyüktür. Diğer taraftan sosyal medyanın tehlikeli bilgi paylaşımı ve manipülasyon aracı olarak kullanılmasıyla, gelişmekte olan ülkelerdeki koalisyon hükümetlerinin düşürülmesi; etnik, dini ve mezhepsel çatışmaların körüklenmesi gibi birçok muhtemel riskten söz edilebilir.

Sosyal medyanın tehlikeli bilgi paylaşımı ve manipülasyon için kullanılması, ülke içinden kişi ve gruplarca olabileceği gibi ülke dışından kişi, grup veya istihbarat birimlerince de söz konusu olabilir. Bir ülkede yaşanacak karışıklık ve kaos ortamı ancak o ülkeye zarar vermek isteyen devlet ve örgütlerin (bu örgütler terör ve istihbarat vb. olarak ifade edilebilir) işine yarar. Çünkü bir devlete veya topluma zarar vermenin en kolay yolu iç karışıklık çıkartarak toplum içerisindeki farklı grupları birbirine düşürmektir. Bu karışıklıklar ve kaos ortamları 
sayesinde gücü ve otoritesi zayıflayan devlet yönetimini ele geçirmek veya yönetime istediğini yaptırmak kolaylaşır. Özellikle soğuk savaş dönemini incelediğimizde bu tarz olayların sıklıkla gerçekleştiğini görmekteyiz. Arap baharı örneğinde de görüldüğü üzere, topyekun bir savaş veya silahlı bir mücadelenin hem ekonomik hem de insani yönden büyük kayıplara neden olacağını bilen devlet ve örgütler, bu tarz müdahale yerine, farklı grup ve insanları birbirine düşürme, halk isyanlarını destekleme ve provoke etme taktiğini kullanmayı tercih etmişlerdir. Soğuk savaş sürecinde, savaş ve doğrudan müdahale yerine kullanılan bu tür taktikler, düşman kutupların birbirlerine uyguladıkları en basit ve masrafsız yol olarak karşımıza çıkmaktadır. Bunun içinde her ne nedenle olursa olsun(din, mezhep, irk, siyasi fikir) birbirinden farklı olan kişilerin ve grupların birbirlerine karşı olan hoşgörüsünü ortadan kaldırmaya yönelik çalışma yapmak veya değişik yollarla yapay bir kaos ortamı yaratmak yeterli olacaktır. Yapılan bu çalışma ile devlet veya toplumun kendi gücü ile kendisini yıpratması sağlanır. Bu çalışmaları yapan örgüt yada devletler daha önce ancak basın veya halkın içine soktukları uzun süre güvenlerini kazanmaları için mesai harcamış bireyler (ajan-provokatör) aracılığı ile yapmaktaydılar. Bir şekilde ellerine aldıkları basını kullanarak yalan haber yayma ve ajanlar vasitası ile halk içinde kulaktan kulağa yayılacak kışkırtıcı dedikodularla istediklerine ulaşmaya çalışmaktaydılar. Fakat sosyal medyanın gelişmesi ile farklı bir durum ortaya çıkmıştır. Sosyal medya, güçlü ülkelere diğerlerine karşı, özellikle istihbarat elamanları ve lobiler aracılığıla eskisinden daha masrafsız ve daha az riskle müdahale olanağı sunmaktadır. $\mathrm{Bu}$ amaçla dünyanın herhangi bir yerinden internet üzerinden istenilen provokasyonu başlatmak, sürdürmek ve yönetmek kolaylaşmıştır.

\section{Sonuç ve Değerlendirme}

Sosyal medya, bireylere toplumsal yaşam ve devlet yönetimine katılmadan, eğitim ve ticarete kadar birçok alanda değişik olanaklar sunmakla birlikte; birey, toplum, kamu düzeni ve devlet açısından önemli tehditleri de içinde barındırmaktadır. $\mathrm{Bu}$ tehditlerin en başında sosyal mühendislik saldırılarıyla bir ülkenin yönetimini etkileme veya değiştirme faaliyetlerine olanak sağlaması gelmektedir. Diğer yandan sosyal medya, provokasyona, dezenformasyona ve bilgi kirliliğine neden olma potansiyeli yüksek bir ortamdır. Ayrıca bu ortam niteliği gereği, bağımlık, ailevi sorunlar, tehlikeli bilgi paylaşımı ve manipülasyonlar, ekonomik kayıplar, mahrem sırların deşifre olması, özel hayatın gizliliğinin ortadan kalması gibi bir çok riski içinde barındırmaktadır.

Sosyal ağların kişisel ve kurumsal tehditlerini azaltabilmek için alınması gereken önlemler arasında, sosyal ağlarda kişisel bilgilerin korunması için kullanıcıların bilgi güvenliği farkındalığının artırılması, korumaya dayalı sosyal ă modelleri geliştirilmesi, sosyal paylaşım sitelerinin uygulama katmanı güvenliğinin standartların ötesinde yeniden ele alınarak gerekli düzenlemelerin yapılması sayılabilir. "Devlet sırrı" niteliğindeki bilgilerin korunabilmesi için kamu kurumlarının ve kamu görevlilerinin bu alandaki bilgi birikimlerini artırmaları da büyük önem taşımaktadır. Kişi ve kurumların tehdit ve tehlikeleri dikkate alarak öncelikle kısa, orta ve uzun vadeli stratejilerini belirlemeleri ve bu ortamları ona göre kullanmaları veya bilgilerini ona göre paylaşmaları şarttır. Sosyal ortamda bulundurdukları veya bulunduracakları bilgileri gözden geçirdikten sonra bu ortamlarda yayımlamalarının daha faydalı olacağı, konu hakkında bilgisi olmayan kurumların ise bu konuda danışmanlık almalarının daha faydalı olacağı değerlendirilebilir.

Özetle, sosyal medyanın ortaya çıkaracağı muhtemel riskleri azaltabilmek için, yasal düzenleme eksikliklerinin giderilmesi, eğitim yoluyla çocukların, gençlerin ve genel olarak toplumun bilinçlendirilerek sosyal medya okuryazarlığının geliştirilmesi, siber saldırılara ve bilgi kirliliğinin önüne geçilebilmesi için alt yapının güçlendirilmesi ve nitelikli personelin yetiştirilmesi büyük önem taşımaktadır.

\section{Kaynaklar}

Amin, Samir (2011), Ending the Crisis of Capitalism or Ending Capitalism?, Pambazuka Press, Dakar, Senegal.

Barbera \& Metzger (2003), "A breakout role for Twitter in the Taksim Square protests?", El Cezire, http://www.aljazeera.com/indepth/opinion/2013/06/20 1361212350593971.html, Erişim tarihi: 02.09.2013.

Boyd, Danah M. \& Nicole B. Ellison (2008), "Social Network Sites: Definition, History, and Scholarship", Journal of Computer-Mediated Communication, 13 (2008),210-230.

Çildan, Cihan, Mustafa Ertemiz, H. Kaan Tumuçin, Evren Küçük ve Duygu Albayrak (2012), "Sosyal Medyanın Politik Katılım ve Hareketlerdeki Rolü”, Akademik Bilişim, Erişim: 05.09.2013, ab. org.tr/ab12/bildiri/205.doc

http://tr.wikipedia.org/wiki/2013_Taksim_Gezi_Park\%C4 \%B1_protestolar\%C4\%B1, Erişim Tarihi 01.09.2013

http://tr.wikipedia.org/wiki/Arap_Bahar\%C4\%B1, Erişim: 10.09.2013

http://tr.wikipedia.org/wiki/Sosyal_medya, Erişim Tarihi 01.09 .2013

http://tr.wikipedia.org/wiki/Sosyal_medya, 08.09.2013

http://www.bthaber.com/\%E2\%80\%98riskleri-bilereksosyallesme\%E2\%80\%99-devri/, Erişim: 10.09.2013

http://www.egm.gov.tr/

http://www.ihd.org.tr/

http://www.serhanyildiz.net.tr/wpcontent/uploads/turkiyede-rakamlarla-internetkullanimi.jpg, Erişim: 10.09.2013

http://www.slideshare.net/symantec/symantec-2011social-media-protection-flash-poll-global-results, Erişim: 10.09.2013

http://www.worldbulletin.net/?aType=haber\&ArticleID=1 10555, Erişim: 15.08.2013

Kartal, Mehmet (2013), “Tükiye'de Sosyal Medya Raporu", İletişim ve Diplomasi Dergisi, http://www.iletisimvediplomasi.com/mehmet-kartalturkiyede-sosyal-medya-raporu/, Erişim: 07.10.2013. 
Nadine Kassem \& Rabia Minatullah Sohail (2011), “The Reasons Social Media Contributed To The 2011 Egyptian Revolution", International Journal of Business Research and Management (IJBRM), Volume (2) : Issue (3) : 2011139

Öğüt, Gürül (2013), “Sosyal Medyaya Global Bakış ve Türkiye'nin Yeri”, Radikal Gazetesi, 19.08.2013

Sharp, Gene (2013), Diktatörlükten Demokrasiye, Albert Einstein Enstitüsü

Sosyal Medyanın Arap Baharındaki Rolü Bilimsel Olarak Kanitland1, http://www.e-siber.com/sosyalmedya/sosyal-medyanin-arap-baharindaki-rolubilimsel-olarak-kanitlandi/, Erişim: 15.09.2013

Turkish Weekly, 'Occupy Taksim' grows in spite of crackdown”, 01.06.2013. http://www.turkishweekly.net/news/151041/-occupy-taksim-grows-inspite-of-crackdown.html Erişim: 18.09.2013.

Wallerstein, Immanuel (2011) "Wallsteet'i İşgal Et Hareketinin Olağan Üstü Başarısı”, 19.10.2011 Çeviren: Taylan Doğan, http://www.bgst.org/kureselkriz/wall-streeti-isgal-et-hareketinin-olaganustubasarisi, Erişim Tarihi 01.09.2013 